Meta

Journal des traducteurs

Translators' Journal

\title{
The Audio-Visual Text: Subtitling and Dubbing Different Genres
}

\section{Zoë Pettit}

Volume 49, numéro 1, avril 2004

Traduction audiovisuelle

Audiovisual Translation

URI : https://id.erudit.org/iderudit/009017ar

DOI : https://doi.org/10.7202/009017ar

Aller au sommaire du numéro

Éditeur(s)

Les Presses de l'Université de Montréal

ISSN

0026-0452 (imprimé)

1492-1421 (numérique)

Découvrir la revue

Citer cet article

Pettit, Z. (2004). The Audio-Visual Text: Subtitling and Dubbing Different Genres. Meta, 49(1), 25-38. https://doi.org/10.7202/009017ar
Résumé de l'article

Tout texte audiovisuel, formé d'éléments verbaux et non verbaux, est complexe. Comment ces éléments influent-ils sur le sous-titrage et le doublage interlinguistique ? À partir d'une sélection de genres audiovisuels (long métrage, série télévisée, informations et documentaire), nous cherchons d’une part à établir jusqu'où le genre audiovisuel peut déterminer la traduction et d'autre part à mieux cerner l'interaction entre le langage et l'image, entre le verbal (restreint au mot parlé) et le non-verbal (en faisant référence aux gestes et à l'intonation). Le caractère multi-sémiotique du média audiovisuel ne saurait être sous-estimé. 


\title{
The Audio-Visual Text: Subtitling and Dubbing Different Genres
}

\author{
ZÖ̈ PETTIT \\ University of Greenwich, London, United Kingdom \\ zoepettit@yebo.fsworld.co.uk
}

\begin{abstract}
RÉSUMÉ
Tout texte audiovisuel, formé d'éléments verbaux et non verbaux, est complexe. Comment ces éléments influent-ils sur le sous-titrage et le doublage interlinguistique? A partir d'une sélection de genres audiovisuels (long métrage, série télévisée, informations et documentaire), nous cherchons d'une part à établir jusqu'où le genre audiovisuel peut déterminer la traduction et d'autre part à mieux cerner l'interaction entre le langage et l'image, entre le verbal (restreint au mot parlé) et le non-verbal (en faisant référence aux gestes et à l'intonation). Le caractère multi-sémiotique du média audiovisuel ne saurait être sous-estimé.
\end{abstract}

\section{ABSTRACT}

This article explores the complexity of the audio-visual text, comprised of both verbal and non-verbal components, and how this impacts upon foreign language subtitling and dubbing. Reference is made to a selection of audio-visual genres: the film, television series, news programme and documentary, in order to demonstrate the extent to which a particular genre influences translation. This article examines the interaction between language and image, between the verbal (concentrating on the spoken word) and the non-verbal (with specific reference to gesture and vocal intonation). The multi-semiotic nature of the audio-visual medium is stressed throughout.

\section{MOTS-CLÉS/KEYWORDS}

audio-visual genres, cultural signs, dubbing, non-verbal, subtitling

\section{Introduction}

The media play an important role in this age of globalisation and global communications. The introduction and subsequent boom in satellite television, plus the Internet, has made the world a much smaller place, allowing different peoples, cultures and languages to interact more frequently. The "screen" is a primary vehicle for this interaction and as a result the audio-visual translator has an increasingly important role to play. The "audio-visual text" is a complex medium. The translator encounters verbal and non-verbal information ${ }^{1}$, meanings openly expressed and others inferred by more subtle forms of communication; a rise in intonation, a gesture accompanying the utterance. The aim of this paper will be to establish the extent to which the different components of the audio-visual message influence English-French translation. The constraints specific to subtitling and dubbing will be pointed out where it is felt that they contribute to the translator's solution. ${ }^{2}$ Reference will be made to both subtitling and dubbing. Furthermore, a number of audio-visual genres will be studied: the film, the television series, the news programme and the documentary. We will discover specific instances where non-verbal features influence the subtitled 
and/or dubbed version and others where the translator has chosen to concentrate solely on the verbal message. This will be explored in relation to the different audiovisual genres which form part of this study. ${ }^{3}$

\section{Background}

As a student of translation and an English mother tongue speaker living in France, I found myself increasingly drawn to audio-visual translation and its implications for language, the viewer and the translator. Upon completing a preliminary piece of research on English-French dubbing and subtitling in a selection of American musicals, I became aware of the complexity of the audio-visual medium and the specific challenges for the translator. Subtitling transposes spoken dialogue into written text in the form of one or two lines at the bottom of the screen. Dubbing necessitates the grafting of a voice belonging to a different person onto the actor appearing on the screen. Sound track and image converge to create meaning. Sounds, vocal intonation, visual signs, gestures, postures, editing techniques all combine to create a message for the viewer to interpret. In other words, what is said is only part of the message. The way it is said, together with visual and auditory markers, form an integral part of the message.

\section{Methodology}

The extracts chosen for analysis were selected in an attempt to answer the following questions:

- How do subtitle, original soundtrack and image fit together?

- What is the nature of the relationship between the image and the newly dubbed soundtrack?

- How is the audio-visual translator affected by culture-specific verbal and visual features?

- What is the role played by non-verbal features in subtitled and dubbed versions and how does it affect the resulting translations?

- For all the above, in what way is the audio-visual genre a significant factor in the resulting translation?

The selection of the corpus was neither arbitrary nor purely subjective. The audio-visual texts chosen belong to a range of genres allowing a comparative analysis of their impact upon subtitling and dubbing. Westerns, musicals and detective films, for example, all have definable characteristics. The genre creates a certain style of expression and consequently affects how the translator transposes the original dialogue if congruency is to be established between the character we see and what (s)he is purported to be saying in the translation. As Kovacic (1998:127) points out, "the genre partly determines the linguistic register to be used."4 Audio-visual genres, in a broader sense, are characterised by different discourse patterns and function in different ways. In films and television series a "performance" takes place. In news programmes, the presenter follows a pre-defined format. In a documentary, the speakers are closest to "being themselves." They are not performing a role or following theatrical norms. The conversations are spontaneous and natural. News programmes and documentaries aim essentially to inform the public whereas films 
and television series serve to entertain their audiences. Yet it is dangerous to establish strict divisions between the different genres as they do overlap. A series and news programme might inform and entertain. ${ }^{5}$ Translating a court scene in a police series may be similar to translating a trial during a news programme (legal jargon, formal register and so forth). Nevertheless, each of these situations fulfils a different function within the context of the programme as a whole. In the first case, the scene forms an integral part of the plot whereas the second informs the viewer about established facts. This might affect the way in which the dialogues are transposed in the subtitled and dubbed versions. For the purpose of this analysis, three films were selected in both their subtitled and dubbed versions (The Piano, Smoke, Blue in the Face), in addition to a subtitled and dubbed television series (NYPD Blue), a subtitled news program (CBS News) and finally, a subtitled documentary (Welcome to the Human Race).

In The Piano two cultures come into contact: the British colonialists and the Maoris of New Zealand. Body language becomes all the more significant in a film where two peoples are unable to communicate verbally and the principal character is mute. The non-verbal and semiotic dimensions of the image have an important function in this film.

The American films, written by Paul Auster and produced by Wayne Wang, offer two representations of Brooklyn in which dialogue is more important than dramatic action. Blue in the Face is interspersed with real-life interviews and alternates between two genres, film and documentary. Smoke follows a script whereas Blue in the Face is characterised by experimentation and improvisation.

N.Y.P.D. Blue was selected for a number of reasons. The quick succession of cuts and the rapid movements of the camera create specific challenges for the audiovisual translator. At the same time it conforms to the typical American police series in which dramatic effects and suspense are paramount. The action also occurs in Brooklyn and enables comparisons with the Auster films.

The subtitler is confronted by a number of issues in CBS News. The journalists speak quickly and a variety of subjects are broached. The subtitler needs a wide general knowledge and as the target public is diverse, some will be experts in the subject matter being treated. It is therefore necessary to eliminate errors and irregularities as far as possible in the subsequent translation. If the target public is an unknown quantity, how does the translator pitch the translation? Subtitles have to be provided quickly in order for the news to be relevant when broadcast in the country of the target language. News programmes also exert considerable amount of pressure on the subtitler due to the sheer amount of information through which the translator is required to sift. (Ivarsson and Carroll, 1998: 102).

The South African documentary Welcome to the Human Race, is composed of interviews by journalists in the field and a narrator (voice over) who intervenes occasionally. Culture-specific features create tensions in the subtitled version. The extent to which the target public might be aware of South African history could vary. Does the subtitler address this in the translation?

\section{Translating the image}

Let us now explore the link between the image and the soundtrack in relation to subtitling and dubbing. In what way is the image a determining factor? In the following 
example from The Piano, the filming of the sequence influences the subtitles. It is situated towards the end of the film, when Ada leaves Stewart. She is in a boat heading towards Australia and we hear her thoughts (voice over). As the piano is thrown overboard, Ada's foot becomes trapped in one of the ropes attaching the piano to the canoe and she is plunged into the water.

\begin{tabular}{|l|l|l|}
\hline English version & Subtitled version & Dubbed version \\
\hline $\begin{array}{l}\text { Down there everything is } \\
\text { so still and silent, }\end{array}$ & $\begin{array}{l}\text { Les profondeurs sont } \\
\text { immobiles et silencieuses. }\end{array}$ & $\begin{array}{l}\text { Là-bas tout est immobile } \\
\text { et silencieux. }\end{array}$ \\
\hline that it lulls me to sleep. & Cela me berce et m'endort. & Cela me berce et m'endort. \\
\hline
\end{tabular}

This extract is followed by a vertical travelling steadily downwards and the image becomes progressively darker. "Down" both anticipates and then describes the movement of the camera as Ada and the piano fall towards the bottom of the ocean. This becomes explicit in the subtitled version with: "Les profondeurs sont immobiles et silencieuses." These nuances are lost in the dubbed translation: "Là-bas tout est immobile et silencieux “.

It is interesting to note the different strategies adopted by the translators in the following extract from N.Y.P.D.Blue. Image and soundtrack are closely linked. Sipowicz arrives at the police station and shows photographs to his colleagues:

\begin{tabular}{|l|l|l|}
\hline English version & Subtitled version & Dubbed version \\
\hline $\begin{array}{l}\text { DONNA: Ah, I, I think you } \\
\text { showed me }\end{array}$ & Vous m'avez déjà montré & $\begin{array}{l}\text { Euh, je crois que vous m’avez } \\
\text { déjà montré }\end{array}$ \\
\hline this one before. & celle-ci. & cette photo. \\
\hline
\end{tabular}

The viewer cannot actually see what is being shown yet this becomes clear due to the context and dialogue. In spite of this the dubber chooses to specify "this one" with the translation "cette photo." As regards the subtitled version, the image is considered sufficient for the viewer to understand the referent of "celle-ci." The link between the image and the translation is therefore reinforced in the subtitled version and lessened in the dubbed version. However, in the examples below, the dubber decides to change the original dialogue in accordance with what appears on the screen:

\begin{tabular}{|l|l|l|}
\hline English version & Subtitled version & Dubbed version \\
\hline SIPOWICZ: Whisky... & Whiskey... & Du whisky... \\
\hline Line them up. & Alignez-les. & Trois petits verres. \\
\hline
\end{tabular}

This example occurs when Sipowicz sits down in a bar and tries to overcome his grief after hearing of the murder of his son. He asks the barman to serve him some whisky. The barman places three tot glasses on the counter and fills them up. The subtitler provides a literal translation whereas the dubber makes the visual information explicit: "Trois petits verres" (“Three small glasses"). The image modifies the way in which the dubber transposes the dialogue. 
Editing and filming techniques also affect the audio-visual translator. ${ }^{6}$ In the following extract, the two detectives, Simone and Greg, interview the first homicide suspect. The speaker is off-screen and due to the movements of the camera at this point, the viewer could misunderstand the subtitled version.

\begin{tabular}{|l|l|l|l|}
\hline Shots & Shot of Simone & Cut. Shot of Greg. & $\begin{array}{l}\text { Cut. Shot of Simone. } \\
\text { Travelling towards the } \\
\text { left. Shot of Bernat. }\end{array}$ \\
\hline English version & $\begin{array}{l}\text { We test your hands } \\
\text { for powder }\end{array}$ & $\begin{array}{l}\text { residue we're gonna } \\
\text { find out }\end{array}$ & you shot that gun? \\
\hline Dubbed version & $\begin{array}{l}\text { Si on cherche des } \\
\text { traces de poudre }\end{array}$ & $\begin{array}{l}\text { sous vos ongles est-ce } \\
\text { qu'on va découvrir que }\end{array}$ & vous vous en êtes servi? \\
\hline Subtitled version & $\begin{array}{l}\text { Si on examine tes } \\
\text { mains }\end{array}$ & $\begin{array}{l}\text { on va trouver } \\
\text { que c'est toi }\end{array}$ & qui a tiré? \\
\hline
\end{tabular}

The first subtitle remains on the screen over the first cut. ${ }^{7}$ The translator has no choice in the matter as the shot change is so quick that if he were to insert a second subtitle, which would be customary practice, the viewer would not have time to read it. Furthermore, the second subtitle "qui a tiré" appears on the screen during the rapid travelling towards the left. This movement of the camera might hinder reading the subtitle. The translator prevents this by inserting an extremely short subtitle, preferring to allow the subtitle to run over the cut than to leave the viewer to read a long subtitle during the travelling. Thus the movement of the camera has been more of a determining factor than the shot change. Several other instances in this extract show how the subtitler is obliged to adjust the translation in accordance with what is happening visually, relating either to the actions of the actors and/or the movements of the camera and editing techniques. The viewer of the dubbed version can watch and listen in the same way as the viewer of the original version and so this sequence does not pose any particular difficulties.

Let us now examine how the image influences the subtitling of CBS News. As the presenter reads the news, pictures appear in the background, complementing his words. The décor of the studio plays an important role. Baggaley and Duck established the significance of "semes" in television. In an experiment it was found that by changing the background, the viewers' perception also changed:

[...] a speaker was shown either against a curtain or against an appropriate photograph. The photograph background did not, as might be supposed, make him more interesting, but did appear to make him more profound, more reliable and more fair; in other words it raised his credibility and increased the amount of trust the viewers were prepared to invest in him. The variation of a seme clearly affected the semantics of the shot. (quoted in: Fiske and Hartley, 1982: 65)

CBS News begins with the following voice over: "This is CBS Evening News... with Dan Rather reporting from CBS News headquarters in New York." This introduction is not subtitled. Dan Rather is seated on a podium behind a wide desk on the front of which we see "CBS" and the logo, which resembles an eye. During the introduction, this symbol is superimposed onto a world map. What could this mean? CBS News is a metaphorical eye that allows us to see the world. In other words, the world becomes 
visible and accessible to those who watch CBS News. Behind Dan Rather, we see a large room with desks, computers, fax machines and the silhouette of a person working. In addition, we see television screens and two large posters, one to the left, one to the right, with "CBS News" and the symbolic logo. The viewer could deduce that the reports have been prepared in the studio where the programme is filmed. The equipment on show and the size of the studio emphasise the resources available to the news channel. The serious nature of the programme and its credibility are thus evoked visually before the presenter even begins to read the news. All this is rapidly, and perhaps unconsciously, recorded by the viewer before the camera zooms in to a head and shoulders shot of the news presenter. This camera movement signals the start of the programme and that the viewer must now concentrate on what is being said. Therefore, the image modifies the audio-visual message. How does this affect the translation?

As regards the subtitled version, the image may affect the way in which the translator chooses to transpose the original. In the following example, image and discourse are closely inter-linked. The audio-visual medium allows the speaker to show what is being referred to verbally. The subtitler chooses to make this explicit in the following example:

\begin{tabular}{|l|l|}
\hline English version & Subtitled version \\
\hline $\begin{array}{l}\text { BILL WHITAKER: The families of the murder } \\
\text { victims Ron Goldman and Nicole Brown Simpson } \\
\text { have been waiting for THIS DAY (i) in court }\end{array}$ & $\begin{array}{l}\text { Les familles des victimes attendaient } \\
\text { CE jour... }\end{array}$ \\
\hline $\begin{array}{l}\text { to face O.J. Simpson and tell the jury of their } \\
\text { pain }\end{array}$ & $\begin{array}{l}\text { confronter Simpson et dire leur douleur } \\
\text { au jury }\end{array}$ \\
\hline ever since THIS DAY (ii) in court. & Depuis l'autre procès... \\
\hline JUROR: “...not guilty of the crime of murder...” & Non coupable... \\
\hline
\end{tabular}

The reporter, Bill Whitaker, repeats "this day" twice. However he refers to a different date each time. In the first instance he refers to present day, when the families finally hope to confront O.J. Simpson. In the second, "this day" refers to a previous moment in court when O.J. Simpson was found to be not guilty. The reporter signals, through intonation and stress, that the second "this day" (ii) is situated in the past. "This day" (ii) takes place before "this day" (i). The image also illustrates that we go back in time to Simpson's reaction of joy when he hears that he has been acquitted. Furthermore, we hear "not guilty of the crime of murder." The subtitler chooses to clarify this reference to a different date. He avoids any possible confusion as "l'autre procès" makes it obvious that the speaker is referring to a different moment in the court proceedings.

In Welcome to the Human Race many of the objects filmed are symbolic as the producer aims to reveal life in the New South Africa after the first democratic elections marking the end of apartheid. In the following extract, the South African flag is filmed:

\begin{tabular}{|l|l|}
\hline English version & Subtitled version \\
\hline BETTY: Look the flag! & - Regardez, le drapeau! \\
\hline ELLEN: That's nice. & - C'est vrai. \\
\hline
\end{tabular}


The speakers are barely audible, yet the subtitler includes a translation in order to emphasise their reference to the flag. A flag is a metonym of a country and is often seen to represent national pride. In this context it is of particular significance as it is the new flag of South Africa. It is free of associations attached to the previous flag and represents a new beginning. All these meanings are evoked, for South Africans or viewers who are aware that this flag is indeed new, when Betty exclaims, "Look the flag!" For those who do not understand the true significance of this remark, the symbolic meaning of the sequence is lost. The subtitler could have perhaps inserted the adjective "nouveau" ("Regardez, le nouveau drapeau"). Although this changes the original, it would help the viewer to understand the significance of this extract.

\section{Transposing culture}

Language and culture are inextricably linked. In his book on visual communication, Worth (1981:4) reveals the different permeations of culture and forms of expression: "When we make films, paint pictures, carve doorposts, dress, set our tables, and furnish our homes, as well as when we speak, we are using symbolic forms which are part of culture and which are all possibly related." In a subtitled version it is evident that the film or programme is foreign as we hear the original dialogues. However, in a dubbed version, the actors speak the public's language. All the same, the image reveals elements which point to the "nationality" of the film. In other words "cultural signs transmitted by visual information [...] complement the verbal subtext in the source text [...]" (Chaume Varela, 1997: 321). This holds true for both dubbed and subtitled versions, but the nature of this interaction changes. In a subtitled version the viewer hears the dialogue in another language, reads the subtitle and watches the picture. In a dubbed version, the viewer listens to a translated version of the original dialogues while watching the original image.

In the same way as language can be broken down into different components which hold meaning, so too can culture-specific elements. Body language or "physical expressiveness" (Shochat and Stam, 1985: 51-52) may be culturally determined. Viewers of a foreign film or television programme come into contact with another way of perceiving the world. The screen vehicles a cultural representation of the world which is situated along a continuum of "similar" to the viewers' cultural system to "remote." Indeed, the programmes and films that form part of this discussion present a number of cultural realities: British colonialists in 19th century New Zealand, Maoris, New Yorkers and South Africans. To what point does the audiovisual translator mediate between the verbally and visually culture specific?

The following example in The Piano, illustrates the way in which the dubbing translator is influenced by essential themes or leitmotivs in the film. These themes are linked to culture specificities in the Western world. Ada and Flora are in their candlelit tent awaiting the arrival of Stewart:

\begin{tabular}{|l|l|l|}
\hline English version & Subtitled version & Dubbed version \\
\hline FLORA: Look, I'm a very & Je suis une grosse mite. & $\begin{array}{l}\text { Regarde, je suis un grand } \\
\text { papillon de nuit. }\end{array}$ \\
\hline Will I catch fire? & Je vais prendre feu? & Je vais me brûler les ailes? \\
\hline
\end{tabular}


The subtitler prefers a literal rendering of the original: "Je vais prendre feu"? However, the dubber takes note of the overall symbolic importance of wings in the film by translating the general "Will I catch fire" with the more specific "Je vais me brûler les ailes?" This translation is in no way prompted by the need for phonetic synchronisation and so reveals that the translator has preferred to introduce one of the important leitmotivs of the film at an early stage. In passing, we also note the translation of "une grosse mite" for "a very big moth." This is unsuitable and adds pejorative connotations not present in the original.

Let us examine the "wings" leitmotiv in greater detail, in order to understand why the dubber has chosen to make explicit reference to them at the beginning of the film. At one point in The Piano, a play is organised by the expatriates. Flora plays the role of an angel and is to wear wings as part of her costume. The paradox becomes clear during the course of the film when we witness Flora's betrayal of her mother. In one of the most dramatic sequences in the film and a turning point for what is to follow, Ada writes the message on a piano key and asks Flora to take it to Baines. However, in an act of defiance, Flora gives the message to Stewart. Furious, Stewart punishes Ada and removes one of her fingers with an axe. He cripples her on two levels: Ada uses her hands to communicate through sign language and as she plays the piano. During this scene, Flora wears the wings that she will have for the play. Wings are often symbolic of liberty. This takes on a specific meaning in a film where the main character is trapped by mutism and imprisoned ${ }^{9}$ by a man she was forced to marry. Wings also have biblical and mythological connotations: angels, the dove and the olive branch, Hermes or Mercury, the winged messenger of the Gods. Flora becomes a messenger for her mother. Her childlike innocence is combined with precocity. The piano key could be the olive branch and Flora the dove. However, in this case Flora is not the harbinger of peace but of a terrible punishment. Prior to this scene, Flora plays outside with the wings attached to her dress as she hums the wellknown British nursery rhyme, "The Grand Old Duke of York":

The Grand Old Duke of York

He had ten thousand men,

He marched them up to the top of the hill,

And he marched them down again.

And when they were up they were up,

And when they were down they were down,

And when they were only halfway up,

They were neither up nor down.

The rhyme reminds the viewer that despite her precocious nature, Flora is a child. At the same time it anticipates the events which follow. Flora, herself, will "march" up the hill to Stewart and hand over the message her mother wrote for Baines. She will be marched back down the hill by Stewart, who in a cold fury, goes to punish Ada. Although Flora only hums the tune, for those who know the rhyme and the words, its symbolic significance becomes clear. Non-verbal information is essential to understanding the semantics of the sequence. Neither the subtitler nor the dubber indicate these nuances and only the French speaker who is cognisant of British nursery rhymes might pick up the symbolic meaning. 
In The Piano, different cultures come into contact. Baines is fully integrated and looks more like a Maori than a European. He is an exception. In the rest of the film, Maoris and Europeans meet but do not understand each other's language or culture. The Maori dialogues are subtitled in both versions and reveal how they value tradition, superstition, and their strong link to their land. The viewer becomes an accomplice to the Maoris and Baines, while Stewart is isolated in his miscomprehension. ${ }^{10}$ The subtitled Maori dialogues reveal their lyricism. In the following extract, the Maoris dialogue is translated in the English and subtitled versions. A Maori touches Ada's face and expresses his wonder:

\begin{tabular}{|l|l|l|}
\hline English version & Subtitled version & Dubbed version \\
\hline $\begin{array}{l}\text { MAORI: Look how pale - } \\
\text { like angels. }\end{array}$ & Elles sont pâles. & - \\
\hline & Comme des anges. & - \\
\hline
\end{tabular}

The dubber leaves the viewer to work out what is being intimated from the Maori's intonation and actions. However, the translation is significant in that it reveals the Maoris spiritualism. Their unkempt appearance is contrasted with the poeticism of what they say and forms an integral part of their characterisation. This is lost in the dubbed version.

Let us now move onto Smoke and Blue in the Face. In these films we are shown the reality of Brooklyn. We witness both the stereotypical violence often associated with this borough and also the natural warmth of the Brooklyn population. The former is typified by the two gangster characters in the form of Charles Clemm and Roger Goodwin. Their physical appearance is indicative of the "hoodlum" subset. They are covered in chunky, flashy jewels and Goodwin wears a woollen hat pulled down over his ears. In the following extract, words become superfluous due to the threatening gestures, intonation and volume of their voices:

\begin{tabular}{|l|l|l|}
\hline English version & Subtitled version & Dubbed version \\
\hline $\begin{array}{l}\text { GOODWIN: Do you } \\
\text { understand me? }\end{array}$ & Tu piges? & C'est assez clair j'espère. \\
\hline PAUL: Yes, I understand you. & - & Oui, très clair. \\
\hline
\end{tabular}

Paul replies in a quiet, low voice revealing his fear. He is pinned against the wall and has to submit to this intimidation. His reply is barely audible. However, the movement of his lips is visible and so the dubber provides a translation. The subtitler's rendition of Goodwin's question is interesting in that it changes the register of the original "Do you understand me?" to the more familiar "Tu piges?" It conveys Goodwin's threatening attitude and is in keeping with the general atmosphere. Clemm and Goodwin's language use confirms they are criminals. They use the double negative throughout: "Ain't nobody calls Charles by that name to his face" or "you don't want no unpleasant surprises now do you?" The same observation can be made with reference to N.Y.P.D Blue when a petty criminal is interrogated by the detectives: 


\begin{tabular}{|l|l|l|}
\hline English version & Subtitled version & Dubbed version \\
\hline $\begin{array}{l}\text { 1) MIKE: I w... I don't } \\
\text { know nothing about that. }\end{array}$ & Je sais que dalle. & $\begin{array}{l}\text { Eh, eh, je sais même pas où } \\
\text { il se trouve. }\end{array}$ \\
\hline $\begin{array}{l}\text { 2) MIKE: I mean we didn't } \\
\text { know yous was a cop. } \\
\begin{array}{l}\text { Y'know.We thought you } \\
\text { was gonna kill us. }\end{array}\end{array}$ & $\begin{array}{l}\text { On savait pas que vous } \\
\text { étiez flic. On a cru que } \\
\text { vous alliez nous tuer. }\end{array}$ & $\begin{array}{l}\text { On savait pas que vous étiez } \\
\text { dans la police. On a vraiment } \\
\text { cru que vous vouliez nous tuer. }\end{array}$ \\
\hline
\end{tabular}

The double negative is translated by omitting the "ne" in the French versions. The subtitler chooses "que dalle" to translate "I don't know nothing about that" and this informal register imitates the general ambiance of the original. The subtitler also prefers "flic" to translate "cop" whereas the dubber chooses "police." This might be due to the need for phonetic synchronisation (the first syllable of "police" is close to "cop"). However, this is not the only time when the dubber opts for a more standard version:

\begin{tabular}{|l|l|l|}
\hline English version & Subtitled version & Dubbed version \\
\hline $\begin{array}{l}\text { 1) SIMONE: That's why } \\
\text { your BUDDY pulled out } \\
\text { that shotgun there }\end{array}$ & $\begin{array}{l}\text { C'est pour ça que ton } \\
\text { POTE a sorti un fusil }\end{array}$ & $\begin{array}{l}\text { C'est pour ça que ton } \\
\text { COPAIN a pris son fusil }\end{array}$ \\
\hline $\begin{array}{l}\text { And you had that piece } \\
\text { under the mattress right? }\end{array}$ & $\begin{array}{l}\text { Et que t'avais un flingue } \\
\text { sous le matelas? }\end{array}$ & $\begin{array}{l}\text { et que t'avais un pistolet } \\
\text { sous ton matelas, mm? }\end{array}$ \\
\hline $\begin{array}{l}\text { 2) MIKE: I, I'm not even } \\
\text { big in that. You know, I'm } \\
\text { a DRUNK. }\end{array}$ & $\begin{array}{l}\text { C'est même pas mon truc. } \\
\text { Moi, je PICOLE. }\end{array}$ & $\begin{array}{l}\text { J'suis même pas porté sur ça. } \\
\text { C'est vrai. Moi, c'est plutôt } \\
\text { l'ALCOOL. }\end{array}$ \\
\hline
\end{tabular}

In the first example, the subtitler prefers the familiar word "pote" to translate "buddy" whereas the dubber opts for the more standard "copain." In the second example, the subtitler uses the verb "picoler" to transpose the statement "I'm a drunk" ("Je suis un ivrogne") yet the dubber prefers "alcool." The subtitler uses spoken forms of the language whereas in the dubbed version, the dialogues have been neutralised and do not seem to fit the character we see on the screen.

\section{Two aspects of non-verbal communication: Vocal intonation and gesture}

The audio-visual text allows the viewer to observe different forms of behaviour in a variety of situations. Films and television programmes imitate a certain kind of reality, projecting an image, a reflection of the way in which human beings communicate with each other and their world. Tone of voice, intonation, gestures may all affect the way in which the verbal content is perceived. The audio-visual medium enables the viewer to experience different forms of expression. Clerc $(1993: 12)^{11}$ proposes that the screen is a visible manifestation of abstract entities. Fodor (1969: 81) maintains that the kind of gesture and its intensity "depend on the personality of the speaker, on the speech context and situation, on what is being conveyed in words, and last but not least, on the nationality of the person speaking." Similarly, in certain situations, a 
character's body language may contradict what is being said. Kendon (1981: 8) refers to Poyatos and concludes that it is extremely difficult for a writer to transmit the richness of human communication when it comes to non-verbal communication. As subtitling is a written form of the language we could say that it experiences similar limitations. At the same time, the soundtrack helps to replace some of the information omitted from the subtitles.

Let us examine a selection of extracts where intonation changes the meaning of the original. The following example is taken from Smoke:

\begin{tabular}{|l|l|l|}
\hline English version & Subtitled version & Dubbed version \\
\hline $\begin{array}{l}\text { PAUL: A little less clumsiness } \\
\text { would be nice, don't you think? }\end{array}$ & $\begin{array}{l}\text { Fais un peu plus d'attention! } \\
\text { ne serait pas inutile! }\end{array}$ & Un certain effort d'attention \\
\hline
\end{tabular}

Paul's irritation is clear not only from what he says but in the way he says it (intonation and accentuation). The dubber retains the irony of the original unlike the subtitler who indicates Paul's irritation but not his irony. In the following example, this time from NYPD Blue, the dubber once again chooses to explicate the intonation of the original:

\begin{tabular}{|l|l|l|}
\hline English version & Subtitled version & Dubbed version \\
\hline $\begin{array}{l}\text { DIANE: Bobby, what're } \\
\text { you doin'? }\end{array}$ & Bobby, qu'est-ce que tu fais? & Bobby, tu es fou. \\
\hline
\end{tabular}

This example takes place prior to the two detectives breaking into a trailer to arrest two suspects. Instead of waiting for back-up Bobby decides to proceed with the arrest. His partner, Diane, knows what he is doing. She questions the fact he is acting without back-up and tries to stop him. The subtitler offers a literal translation but the dubbed version explains what she thinks of his action: "Bobby, tu es fou" ("Bobby you are mad").

In the following example, from CBS News, the speaker's emotion is expressed through repetition, accentuation and intonation.

\begin{tabular}{|c|c|}
\hline English version & Subtitled version \\
\hline $\begin{array}{l}\text { OWNER OF A PRIVATE POSTAL SERVICE: } \\
\text { “THEY'RE part of the Federal government, } \\
\text { and THEY have a lot of things that THEY don't } \\
\text { have to do }\end{array}$ & $\begin{array}{l}\text { En tant qu'administration fédérale, } \\
\text { ils sont dispensés }\end{array}$ \\
\hline $\begin{array}{l}\text { that I do. THEY don't have to pay rent like } \\
\text { I'M doing, and that kind of thing. }\end{array}$ & $\begin{array}{l}\text { de certaines choses comme payer } \\
\text { un loyer ou des impôts. }\end{array}$ \\
\hline
\end{tabular}

The speaker expresses her unhappiness by accentuating the words "they" and "I" establishing a division between the two: "they" as opposed to "me." The critical tone is attenuated in the subtitle and her emotion is not transmitted. Similarly, in the following example from Welcome to the Human Race, the double meanings are expressed through intonation and gesture. 


\begin{tabular}{|l|l|}
\hline English version & Subtitled version \\
\hline $\begin{array}{l}\text { ELLEN: And when you hear somebody coming } \\
\text { to say }\end{array}$ & Aussi, quand quelqu'un vient vous dire: \\
\hline "Welcome to the Human Race," & "Bienvenue parmi la race des hommes" \\
\hline when indeed he is degrrrading you, & $\begin{array}{l}\text { alors même qu'il est en train de vous } \\
\text { humilier, }\end{array}$ \\
\hline $\begin{array}{l}\text { you can only but sympathise with that type } \\
\text { of person. }\end{array}$ & $\begin{array}{l}\text { on ne peut qu'éprouver de la compassion } \\
\text { pour lui. }\end{array}$ \\
\hline
\end{tabular}

The speaker's anger is revealed through her body language (repetitive wagging of her forefinger). She also accentuates "degrading" lengthening the "r." When she says "you can only but sympathise with that type of person" her intonation indicates her contempt. At the same time she nods her head several times. She does not literally feel sympathy, "de la compassion." Her remark is therefore ironic yet this is not made clear in the subtitle.

Gesture sometimes influences the translator's rendition of the original. This is illustrated in the following examples from Blue in the Face:

\begin{tabular}{|l|l|l|}
\hline English version & Subtitled version & Dubbed version \\
\hline $\begin{array}{l}\text { A MAN WITH UNUSUAL } \\
\begin{array}{l}\text { GLASSES } \\
\text { shuttle I launch, and as the } \\
\text { shuttle was taking off, }\end{array}\end{array}$ & $\begin{array}{l}\text { Je suis allé au lancement } \\
\text { d'une navette spatiale. } \\
\text { Au décollage... }\end{array}$ & $\begin{array}{l}\text { Je suis allé au lancement d'une } \\
\text { navette spatiale. Et au décollage } \\
\text { de cette navette }\end{array}$ \\
\hline $\begin{array}{l}\text { I could put the binoculars } \\
\text { right in, }\end{array}$ & j'ai placé les jumelles... & j'ai pu placer les jumelles LÀ... \\
\hline $\begin{array}{l}\text { right in, straight through my } \\
\text { frames... because there } \\
\text { is [sic.] no lenses there... }\end{array}$ & $\begin{array}{l}\text { dans mes montures, } \\
\text { il n'y a pas de verres. }\end{array}$ & $\begin{array}{l}\text { Juste dans les montures } \\
\text { COMME ÇA, parce qu'il, } \\
\text { il n'y a pas de verres et euh... }\end{array}$ \\
\hline
\end{tabular}

Lou Reed explains why his glasses are original as can lift up the lenses and look through the frames. He shows how he does this. In the dubbed version, "là" and "comme ça" are inserted at the appropriate moments, coinciding with Reed's gestures. However, the subtitler does not reinforce this, leaving the image to complete what has been omitted. In the example below, the actions influence the subtitler:

\begin{tabular}{|l|l|l|}
\hline English version & Subtitled version & Dubbed version \\
\hline $\begin{array}{l}\text { A MAN WITH UNUSUAL } \\
\text { GLASSES: Let me explain } \\
\text { what the glasses are. }\end{array}$ & Je vais te montrer... & $\begin{array}{l}\text { Je vais t'expliquer ce que sont } \\
\text { mes lunettes. }\end{array}$ \\
\hline $\begin{array}{l}\text { The glasses only have lenses } \\
\text { on top. }\end{array}$ & Les verres sont au-dessus. & $\begin{array}{l}\text { Les verres sont, tu vois? } \\
\text { Au-dessus, là. }\end{array}$ \\
\hline
\end{tabular}

"Let me explain what the glasses are" is subtitled by "Je vais te montrer..." or "I'm going to show you," which is indeed what he then proceeds to do. The gesture has determined the subtitler's choice. 


\section{Conclusion}

Non-verbal information which indicates what the speaker truly means, changing the denotative meaning of the original, sometimes leads the subtitler and dubber to alter their translations appropriately. Implied meanings often become explicit. However, culture-specific visual information tends to be left for the viewer to interpret. When vocal intonation, accentuation and gesture dramatically change the verbal meaning, this is reflected in the subtitles. With the dubbed versions, changes are made to help the new soundtrack "ring true" and match the screen image. This is not always achieved and we have seen examples where the dialogue does not correspond to the character we perceive. In the examples analysed, the dubber often prefers to standardise and simplify the dialogues. Similarly, the subtitler alters the original utterance according to the gestures and the action. This could be a strategy used to create a stronger link between the new dialogue and the original image.

The audio-visual genre does seem to affect the transposition of the dialogues. In essence, when transposing a film or television series, the translators tend to portray to their audience the spirit and heart of the work, rather than striving to provide a pure literal translation of the spoken words. With the news programme and the documentary, the subtitler prefers to remain very close to the original dialogue ensuring that the audience will receive the essential facts with aesthetic concerns being of lesser importance.

\section{NOTES}

1. For definitions and discussion of non-verbal communication see Argyle (1988), Corraze (1980), Kendon (1981). With specific reference to audio-visual translation and non-verbal components see Chaume Varela (1997), Gambier and Suomela-Salmi (1994), Gottlieb (1994a) and Zabalbeascoa (1997).

2. For a closer look at the spatial and temporal constraints in subtitling and dubbing see Ivarrsson and Carroll (1998), Minchington (1999), Marleau (1982).

3. These findings are based on my doctoral thesis: "Subtitling and dubbing: Interaction between language and image in a selection of audio-visual genres," presented and obtained in May 2000, at Université Paul Valéry, Montpellier, France.

4. See James who proposes "[...] a classical period drama requires a literary language whereas a daily soap opera requires a more spontaneous and colloquial style. A news programme or documentary calls for subtitles which are full of facts presented in a journalistic manner, sometimes in bullet-like fashion." (James, 1998: 250)

5. The American notion of "infotainment" is often used to describe this.

6. See De Linde and Kay (1999).

7. This is not usually the case. For further information see Minchington (1999), Carroll and Ivarrsson (1998)

8. "Identifying a code depends ultimately on our ability to identify its smallest signifying unit, or the base of its hierarchy. This is generally known as the seme, but the term has been applied particularly to visual signs. In the written language, the smallest signifying unit is the letter" (Fiske and Hartley, 1982: 64).

9. Indeed, clothing also reveals her imprisonment: "The period costumes of cumbersome hoop skirts become a linguistic symbol as Campion shows them restraining and expressing Ada's world." (Real, 1986: 172). Ada's hair, scraped back and tied up, becomes a further visual metaphor of restraint.

10. Gottlieb (1994b) makes a similar point when he refers to the Danish subtitled version of Dances with Wolves. During a scene with Kevin Costner and Indians, the dialogues switch from English to Lakota: “[...] the Danish video audience 'understands' what the chief says, while the film hero does not know a word of Lakota. An equally acceptable strategy would have been to let the audience side with the protagonist, sharing his uneasiness about the situation, by not subtitling the remarks in Lakota." 
11. "L'écran permettait la matérialisation visible de ce qui avait toujours été ressenti comme abstrait: les émotions, les états d'âme, mais aussi les qualités et les défauts." (Clerc: 1993, 12)

12. This is the name of the character Lou Reed plays.

\section{REFERENCES}

Argyle, M. (1988): Bodily Communication, 2nd ed., London, Routledge.

Chaume Varela, F. (1997): “Translating Non-Verbal Information in Dubbing," Non-verbal Communication and Translation: New Perspectives and Challenges in Literature, Interpretation and the Media. Fernando Poyatos (ed.), Amsterdam: John Benjamins.

Clerrc, J.-M. (1993): Littérature et cinema, Paris: Editions Nathan.

Corraze, J. (1980): Les communications non-verbales, Paris: Presses Universitaires de France.

De Linde, Z. and N. Kay (1999): The Semiotics of Subtitling. Manchester: St Jerome Publishing.

Elam, K. (1980): The Semiotics of Theatre and Drama, London: Routledge.

Fiske, J. and J. Hartley (1982): Reading Television, London: Methuen.

Fodor, I. (1969): "Linguistic and Psychological Problems of Film Synchronisation," Acta Linguistica Academiae Scientarum Hungaricae, 19 (1-2 \& 3-4).

Gambier, Y. (ed) (1996): Les transferts linguistiques dans les médias audiovisuels. Villeneuve d'Ascq: Presses Universitaires du Septentrion.

Gambier, Y. and E. Suomela-Salmi (1994): "Audiovisual Communication. Problems and Issues at Stake in Subtitling," Intercultural Communication, Actes du 17e colloque LAUD, 23-27 mars 1992, Frankfort: Peter Lang.

Gottlieb, H. (1994a): "People Translating People," Teaching Translation and Interpreting. Insights, aims and visions 2, Amsterdam: John Benjamins, pp. 261-274.

Gotтlieb, H. (1994b): “Subtitling: Diagonal Translation." Perspectives: Studies in Translatology 1, pp. 101-121.

Ivarsson, J. and M. Carroll (1998): Subtitling, Sweden, TransEdit HB.

James, H. (1998): "Screen Translation Training and European Cooperation," Translating for the Media, Yves Gambier (ed.) Turku: University of Turku, pp. 243-258.

Kendon, A. (1981): "Introduction: Current Issues in the Study of Nonverbal Communication," Nonverbal Communication, Interaction and Gesture: Selections from Semotica, Thomas A. Sebeok (ed.), pp. 1-53.

Kovacic, I. (1998): “Language in the Media. A New Challenge for Translator Trainers," Translating for the Media, Yves Gambier (ed.), Turku: University of Turku, pp. 123-129.

Luyken, G.-M. et al. (1991): Vaincre les barrières linguistiques à la télévision: Doublage et soustitrage pour le public européen. Düsseldorf: The European Institute for the Media.

Marleau, L. (1982): “Les sous-titres: un mal nécessaire," META, 27 (3), pp. 271-285.

Minchington, J. (1999): Sub-titling. Hertfrordshire, England.

Real, M. (1996): "Gender Analysis: Patriarchy, Film Women and The Piano," Exploring Media Culture. A Guide, London: Sage, pp. 171-207.

Shochat, E. and R. Stam (1985): “The Cinema after Babel: Language. Difference, Power," Screen, 26 (3-4), pp. 35-38.

Worth, S. (1981): Studying Visual Communication. Philadelphia: University of Pennsylvania Press.

Zabalbeascoa, P. (1997): "Dubbing and the Nonverbal Dimension of Translation," Nonverbal Communication and Translation: New Perspectives and challenges in Literature, Interpretation and the Media, Fernando Poyatos (ed.), Amsterdam: John Benjamins, pp. 327-343. 